\title{
Vertaisuuden tunnustaminen esimiesorientaationa
}

\author{
Verme-koulutus jaettua \\ johtajuutta kehittämässä
}

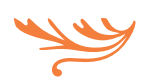

\begin{abstract}
Vastikään tehtäviinsä nimetyille päälliköille suunnatussa koulutuksessa haettiin vertaisryhmätyöskentelyä johtamisen orientaatioksi. Miten päällikön ja työntekijän uudenlainen suhde rakentuu hegeliläisen tunnustuksen käsitteen lähtökohdasta?
\end{abstract}

$\mathbf{y}$ TUTKIMME VERTAISUUDEN tunnustamista esimies-työntekijäsuhteessa vertaisryhmämentorointikoulutuksessa, tutummin verme-koulutuksessa. Siinä tehtäviinsä nimitetyt päälliköt hakivat uutta orientaatiota esimiestyöhönsä. Tavoitteemme on osoittaa vertaisuuden tunnustamisen merkitys uuteen johtamisorientaatioon kasvamisessa vermekoulutuksen ja -työskentelyn tukemana. Empiirisessä materiaalissa tarkastelemme, kuinka noviisipäälliköt neuvottelevat rooliaan ja ottavat paikkansa työyhteisössään ja esimieskoulutuksessaan työorganisaation muutoksessa.

Olemme kiinnostuneet siitä, millaisilla asioilla on merkityksensä uuden roolin ottamisessa ja kuinka vertaisryhmämentoroinnin malli tukee vertaisuuden tunnustamista ja tarjoaa uudenlaista johtamisorientaatiota.
Empiirinen aineistomme etsii vastauksia seuraaviin kysymyksiin:

- Miten vertaisuuden tunnustaminen onnistuu päällikkö-työntekijäsuhteessa?

- Kuinka pysyviä päälliköiden uudet, koulutuksessa omaksutut orientaatiot ovat muutostilanteessa?

Esittelemme ensin vertaisryhmämentoroinnin koulutusohjelman ja kerromme, kuinka sitä käytettiin päälliköiden kouluttamisessa uuteen rooliinsa. Sen jälkeen avaamme saksalaiselta historian- ja valtiofilosofilta Georg Wilhelm Friedrich Hegeliltä (17701831) juontuvan hegeliläisen tunnustuksen käsitteen. Seuraavaksi rakennamme yhteyden tunnustuksen ja vertaismentorointi- eli verme-työskentelyn ja johtamisen käsitteen välille. Sen jälkeen kuvaamme 


\section{VERME TUKEE}

NOVIISIOPETTAJAN

\section{AMMATILLITSA KEHITTYMIST $\ddot{A}$}

URAN ALKUVAIHEESSA.

aineistoamme ja sen analyysitapaa. Näiden perusteella käsittelemme empiirisen aineiston tuloksia. Lopuksi tarkastelemme kriittisesti vermen paikkaa ja soveltumista vertaisuuden tunnustuksen omaksumiseksi ja johtamisen uudeksi pääomaksi sekä pohdimme filosofis-teoreettisen tunnustuksen käsitteen soveltuvuutta päällikköposition rakentamisessa.

\section{VERTAISRYHMÄMENTOROINTI ELI VERME}

Vertaisryhmämentorointi on alun perin ymmärretty toimintamalliksi, jolla autetaan noviisivaiheen opettajien ammatillista kehittymistä heidän siirtyessään työhönsä kouluissa (ks. enemmän historiasta Heikkinen, Jokinen \& Tynjälä 2012). Nykyisin vermeä käytetään ammatillisessa koulutuksessa henkilöstön kehittämisprosesseihin.

Malli tukeutuu formaalin ja informaalin oppimisen yhdistämiseen: ennalta strukturoimattomat informaalit keskustelutilanteet ja kokemusten vaihdot toimivat osallistujien työn ja työyhteisön käytäntöjen kehittämisen ja käsitteellistämisen apuna. Verme-koulutuksessa ei ole käytössä yhtenäistä mallia, mutta koulutuksen käytäntöön on kuulunut 10 päivän mittainen lähijaksotyöskentely. Ehdottomana edellytyksenä on pidetty sitä, että osallistuja kokoaa omasta työyhteisöstään verme-ryhmän, jonka kokoontumisia hän ohjaa lukuvuoden aikana kuudesta kahdeksaan kertaan.

Haaga-Helia Ammatillinen opettajakorkeakoulu on osallistunut 2010-luvun alusta lähtien valtakunnalliseen verme-kehitystyöhön (ks. mt.). Sen mallissa verme-koulutuksen olennaisen osan ovat muodostaneet koulutuksen aikaiset tutkimustehtävät. Niiden avulla osallistujat kaappaavat tehtävän mukaisia ilmiöitä ja tapahtumia omasta työstään, työorganisaatiostaan ja verme-ryhmien keskusteluista sekä käsitteellistävät omaa toimintaansa.
Verme-malliamme kannattelee neljä tutkimustehtävää. Nimittämällä ne tutkimustehtäviksi korostamme autenttisen materiaalin merkitystä koko koulutustoimintamme lähtökohtana: tutkimme organisaatioita, verme-ryhmiä ja osallistujien omia orientaatioita. Lähtökohtamme auttaa sekä asemoimaan itsemme että koulutukseen osallistujat ottamaan näkökulmia, joista käsin mahdollistuu päästä sopivasti etäännytettynä muutoin "liian" lähellä olevan todellisuuden ja ilmiöiden kimppuun (ks. myös Heinilä \& Tapani 2011).

Tutkimuksemme kohteena olevaan verme-toteutukseen hakeutui kaksi oppilaitosta, jotka olivat yhdistymässä ja halusivat muutostilanteessa kouluttaa omat päällikkönsä uuteen rooliin organisaatiossaan. Organisaatiot sijaitsivat eri paikkakunnilla ja maakunnissa usean sadan kilometrin päässä toisistaan, mutta niillä oli yhtäläinen arvoperusta.

Osallistujia oli 13, kaikki päällikköasemassa; heistä 10 oli naisia. Kolmesta neljään osallistujaa oli jo aiemmin toiminut esimiesasemassa samassa organisaatiossa. Koulutuksen alussa olimme kouluttajina jokseenkin tietämättömiä siitä, millaisessa todellisuudessa ja informaaleissa prosesseissa osallistuvat opettaja-pääliköt elivät ja työskentelivät. Ennen toteutuksen alkua neuvottelimme tilanteesta organisaation silloisen, vaihtosiirtymässä olleen johdon kanssa.

Kun organisaatio oli tehnyt päätöksen osallistumisestaan, jouduimme tarkentamaan koulutuksen kohdetta ja tavoitetta. Päädyimme hahmottelemaan usean keskinäisen neuvottelun kautta tilannetta ja toimintatapaa, joka soveltuisi kyseiselle ryhmälle. Lähtökohtaisesti märïttelimme toteutuksen niin, että sillä tuettaisiin "esimies- ja johtamistyön muutosta" verme-työskentelyn pedagogisilla menetelmillä kohti uudenlaista esimiestyötä. Olimme aiemmin kirjoittaneet uuden työn tuomista muutoksista ja sen ammatillista koulutusta koskevista vaikutuksista (ks. Alanko-Turunen \& Pasanen 2009; 2012).

Pedagogisilla menetelmillä tarkoitamme tässä yhteydessä kehittelemiämme vertaisryhmämentoroinnin menetelmiä ja työskentelytapaa, jossa vuorottelevat lähijaksot - yhteensä 10 päivää - neljästä viiteen tutkimustehtävää ja osallistujien oma toiminta vetämissään ryhmissä. Prosessi kestää noin yhdeksän 
kuukautta, ja tutkimustehtävät sekä verkkoalustan keskustelut pitävät kehittämistä yllä yhteisten tapaamisten välissä. Tutkimustehtävät tuovat samalla osallistujien toimintakentältä käytännön materiaalia, jolle lähijaksojen työskentely rakentuu. (Ks. enemmän koulutuksen metodista Alanko-Turunen \& Pasanen 2011; 2013.)

Koulutusprojektissa perehdyimme erityisesti johtamisen kehittymiseen yhtenä työn muutoksen ja uuden työn osana (ks. esim. Jakonen 2014) ja filosofis-teoreettiseen tunnustuksen käsitteeseen.

\section{TUNNUSTUS HIERARKKISESSA SUHTEESSA}

Hegelin tunnustuksen käsite on ollut suomalaisessa koulutuskeskustelussa esillä vain harvoin (ks. Huttunen \& Heikkinen 2004; Miettinen 2016). Filosofi Rauno Huttunen ja vertaisryhmämentorointia kehittänyt Hannu L. T. Heikkinen tarkastelevat asiaa yleensä opiskelijan ja ihmisarvon kunnioituksen ja tunnustuksen näkökulmasta. Työelämätutkimukseen suuntautunut aikuiskasvatuksen emeritusprofessori Reijo Miettinen katsoo asiaa sivistävän merkityksen ja tunnustuksen problematisointina kilpailutaloudessa. Kummassakaan artikkelissa ei käsitellä esiin nostamaamme Hegelin teoksessa tärkeää herran, orjan tai rengin dilemmaa.

Tunnustus on merkittävä tekijä luottamuksen rakentumisessa työelämässä ja sopimusyhteiskunnassa yleensä. Filosofit John Locke ja Jean-Jacques Rousseau loivat 1600-luvulla pohjan sopimusajattelulle, jota Hegel 1800-luvun alussa arvosteli ja täydensi tunnustuksen käsitteellään. Tunnustus on edellytys sille, kuka hyväksytään sopimuskumppaniksi.

Tunnustuksen käsitteellä on ollut vaikutuksensa muun muassa saksalaisen sosiologin Ralf Dahrendorfin konfliktinratkaisuoppeihin, yhdysvaltalaisen filosofin John Rawlsin oikeudenmukaisuusteoriaan, yhdysvaltalaisten psykologien Abraham Maslowin ja Carl Rogersin humanistiseen psykologiaan, rehabilitaationäkemyksiin ja kasvatusfilosofioihin. Tärkeän roolin kasvatuksessa tunnustus saa yleensä ihmissuhteiden perustana ja erityisesti opettaja-oppilassuhteen demokratisoituessa (Huttunen 2009). Johtamisteorioissa spesifi hegeliläinen tunnustuksen käsite on ollut käytössä ainoastaan filosofisten tai psykologisten taustatekstien muodossa. Monissa nykyisissä johtamisnäkemyksissä tunnustus käsitetään ulkoisiksi henkilöstön motivoimisen ja palkitsemisen keinoiksi (esim. Luthans \& Stajkovic 2017). Tästäkin syystä käsitettä on tarpeen koetella käytännössä, etenkin kun työelämän demokratisoituminen myös johtamisessa puhuttaa.

Länsimaiset teolliset demokratiat eivät työssä perustu herra-orja- vaan palkkatyösuhteelle, jossa työntekijä myy aikaansa työnantajalle palkkaa vastaan. Käytämme herra-orja-suhdetta vertauskuvallisesti. Käsittelemme lähinnä työelämää ja työn kehittämistä, vaikka tiedämme kaikkien ihmisen positioiden kytkeytyvän monien suhteiden kautta toisiinsa, ei vähiten työn privatisoitumisen seurauksena (Arendt 2017). On myös havaintoja siitä, että työhön liittyy reaalisia, mutta uudella tavalla "orjamaisia" kehityssuuntia, joissa tunnustuksen käsite saattaa olla käyttökelpoinen kehittämisen ja analyysin väline. Prekarisoituminen koskettaa usein myös asiantuntijoita. Erityisesti näin on silloin, kun työntekijä itse tietää, että voisi käyttää kykyjään syvemmin tehtävissään, jos organisaatio ja instituutio sen sallisivat. Useiden tutkijoiden mukaan etenkin uusi työ sisältää laajoja prekarisoitumisuhkia (Jokinen \& Venäläinen 2015).

Organisaatioissa vallitsevat aina jotkin viralliset ja johtamissuhteet, byrokraattiset käytännöt ja viimekätinen vastuuhierarkia. Tunnustuksen teeman kannalta on kiinnostavaa johtajan ja alaisen valtasuhteen dynamiikka. Hegelin mukaan herran ja orjan valtaalaissuhde on selkeä, mutta kanssakäymisen tulee lopulta johtaa heidän "dialektiseen kumoamiseensa" (Kojève 2012, 19), vaikka tie on dialektisesti kivinen.

Nostamme valtasuhteesta tarkasteluun suvereeniuden, kyvykkyyden ja performatiivisuuden. Hegelillä kaikki inhimillinen, antropogeeninen, itsetietoisuutta, inhimillistä todellisuutta luova halu on viime kädessä tulosta "tunnustuksen" halusta, "ihminen on vain tunnustuksen halua" (mts. 418). Herra on Hegelin mukaan saanut tunnustuksen taistelun kautta vaarantamalla oman henkensä ja pannen näin itsensä likoon. Siksi vain herra on suvereeni subjekti ja voi tunnustaa halutessaan muutoksen orjan asemassa. Tässä suhteessa nyky-yhteiskunnassa 


\section{TunNusTUKSEN TEEMAN}

\section{KANNALTA JOHTAJAN JA ALAISEN}

VALTASUHTEEN DYNAMIIKKA

ON KIINNOSTAVAA.

edelleen vallitsee työnantajan tunnustusoikeus itse työtä koskevissa kysymyksissä.

Herran suvereenius korostuu, koska hänellä on asemansa vuoksi tunnustettu ja vapaa universaali itsetietoisuus. Orja on asemassaan sidottu partikulaariseen ajatteluun ja itsetietoisuuteen, vain toteuttamaan herran elämälle tärkeitä haluja ja päämääriä. Orja tekee herran elämiselle välttämättömän työn, joka on universaalisti muutoin arvotonta (ks. Arendt 2017). Ainoastaan herra voisi tunnustaa orjan potentiaalit, joita tämä itse ei asemansa vuoksi voi edes haluta tunnustetuksi.

Vaikka orjalla olisikin sisäinen potentiaali universaaliin ajatteluun, järjenkäyttöön ja tasavertaisuuteen, hän ei tunnustuksen puutteen vuoksi kykene aktualisoimaan potentiaaliaan (ks. Roman-Lagerspetz 2016, 28-29). Lausumassa tulee esille se ehdoton periaate, että ainoastaan herralla on kaiken tunnustuksen oikeus, koska muutoin nousee kolme ongelmaa.

Ensinnäkin herran saadessa orjalta tunnustuksen, se on alempaa tullessaan mitätön herran itsetietoisuudelle ja potentiaaleille. Toiseksi, jos herra tunnustaa orjan potentiaalit, herra-orja-suhde lakkaa. Kolmanneksi herran täytyy jatkaa taistelua ylöspäin, josta tunnustuksen saaminen on sopivaa ja arvokasta. Herra on siten kaikin tavoin suvereenissa valtapositiossa, vaikka on dialektisesti, toisin sanoen reaalielämässä, riippuvainen orjasta. Hänen käsissään on näin myös valinta, millä tavoin, jos ollenkaan, orja ja orjan potentiaalit tulevat tunnustetuiksi. Siksi herran asenne on kuitenkin eksistentiaalinen umpikuja (Kojève 2012, 27).

Jos päämääränä on vertaisuus ja dialogi - kuten lopulta Hegelin historianfilosofiassa - herralta vaaditaan suvereenin asemansa perusteella kahta toimintaa. Herran on ensimmäiseksi tunnistettava orjan potentiaalit ja toiseksi tunnustettava ne.

Viemme herran ja orjan suhteen metaforan lähemmäs todellista työelämää ja sen positioita. Käsittelemme potentiaaleja ja tunnustamisen performatiivisuutta, jotka molemmat Hegel itse nostaa hyvin tärkeinä esiin. Potentiaalit eivät ole aina näkyviä, ja työntekijä itsekin saattaa olla niiden osalta pimennossa, "impotenssin tilassa" (ks. käsitteestä Elmgren 2015).

Johtaja on hegeliläistä metaforaa seuraten lopulta asemansa vuoksi vastuussa työntekijän potentiaalien parhaasta käytöstä. Käytämme vastuujaottelua eksistentiaalisiin, eettisiin ja epistemologisiin potentiaaleihin. Johtajalla on vastuu siitä, miten potentiaalit tulevat havaituiksi ja tunnistetuiksi ja kuinka ne toteutuvat työntekijän työssä ja positiossa. Prosessissa on tärkeää, että vertaisuuden tunnustamiseksi työntekijällä eli alaisella on havaittava olevan jotakin vertaiseksi tunnustamisen kannalta ennestään havaitsematonta: ominaisuuksia tai tukahdutettua potentiaalia. Vasta sen perusteella hänet voidaan tunnustaa dialogikumppaniksi (ks. myös RomanLagerspetz 2016). Jäädessään tunnustamatta potentiaalit joka tapauksessa jäävät vain erityisiksi ja irrallisiksi teoiksi ilman kokonaisuuden ymmärrystä ja universaalin toiminnan henkeä (ks. Kojève 2012, 178-180).

Mahdollisesti kriittisin vaihe koskee itse tunnustuksen performatiivisuutta eli sitä, kuinka tunnustus tapahtuu toiminnassa. Tunnustaminen itsessään on toimintaa, jonka keskeisin ulottuvuus - kuten koko Hegelin filosofianhistorian - on ajallisuus ja reaalielämän dialektinen eteneminen. Tunnustuksen prosesseilla, käytännössä tunnustamisella, on merkittävät vaikutukset itsetietoisuuden rakentumisen kautta myös tunnustetuksi tulemisen tunteelle ja itsearvostukselle (ks. Huttunen 2003, 99).

Prosessi viittaa sekä muutokseen organisaatioiden toiminnassa ja tekijöiden toimintatavoissa että kehittymisen ja kasvun mahdollisuuteen, jonka tunnustuksen prosessit saavat edetessään aikaan. Tunnustuksen ja arvostuksen kehä rakentaa Huttusen mukaan vahvan yhteenkuuluvuuden tunteen, jolla on positiiviset vaikutukset koko yhteisön toimintaan (mt., 105-106). Saksalaisen filosofin ja sosiologin Axel Honnethin (1995) mukaan instituutioita voidaankin arvioida sen mukaan, kuinka hyvin tunnustaminen -tai sen kieltäminen - niissä toteutuu (ks. Miettinen 2016, 68). 
HyPoteESIMME ON,

\section{ETT $\ddot{A}$ ONNISTUESSAAN VERME}

\section{ON VERTAISUUDEN}

TUNNUSTAMISEN VÄLINE.

Lähtökohtahypoteesimme on, että onnistuessaan verme on vertaisuuden tunnustamisen väline. Erityisesti verme-työskentely voidaan organisaatiossa ymmärtää ensinnäkin tunnustuksen performaationa eli tunnustamisena käytännössä. Toiseksi verme-koulutus tähtää vertaisuuden tunnustamiseen perustuvan toimintatavan eli orientaation omaksumiseen organisaatiossa.

\section{TUNNUSTAMISEN KYTKÖS JOHTAMISEEN JA VERME-TYÖSKENTELYYN}

Jätämme johtamiskäsitysten historian lukemattomine suuntauksineen sivuun (ks. esim. Juuti 2018; Wilson \& Thomson 2006). Yleisesti johtamiskäsitykset ovat mukailleet työn kehittymisen historian suuria linjoja ja pyrkineet sekä vallitsevien eettisten että eksistentiaalisten ihmisarvojen kunnioittamiseen. Useimmiten ne ovat kuitenkin säilyttäneet eron työntekijän, alaisen ja johtajan rooleihin, vastuisiin ja episteemisen tietämisen eroihin.

Johtamisen nykymalleissa, erityisesti leadership- eli ihmisten johtamisen käsityksissä korostetaan dialogisuutta, osallistamista, jaettua johtamista ja luottamusta. Ihmisen, työntekijän ja asiantuntijan henkilöön sitoutuvat potentiaalit nousevat uuden työn (ks. Julkunen 2008; Jakonen 2014) tuottavaksi pääomaksi, jota ei voi johtaa pinnallisesti tai ulkoapäin (Raelin 2003) eikä hallita ilman, että työntekijät tunnustetaan ja arvostetaan positioissan toimijoina (ks. Eteläpelto, Heiskanen \& Collin 2011). Korkean luottamuksen vallitessa organisaation innovointikyky nousee huippuunsa, minkä vuoksi henkilöjohtamisella on suorat yhteydet taloudellisiin tekijöihin. Uuden työn teorioissa sosiaaliset pääomat muuttuvat talouden moottoreiksi, ja näin johtamisen uudet muodot nousevat taloudellisiksi kilpailutekijöiksi. (Putnam 2000; Raelin 2011; Lazzarato 2014).
Vaikka hegeliläinen herra-orja-retoriikka onkin jäänyt syrjään, johtamisen kirjallisuudessa on edelleen luontevaa käyttää muun muassa alaisen käsitettä itsestäänselvyytenä (esim. Juuti 2018). Tunnustuksen käsitteelle on uusissa johtamismalleissa paikkansa etenkin silloin, kun itse työ perustuu yhä enemmän persoonaan sitoutuneeseen osaamiseen, jakamiseen ja vaihtoon ja kun sitä samalla puitteistavat uudenlaiset ansaintalogiikat ja taloudellisuusvaatimukset. Tällöin myös johtamisen edellytykset muuttuvat, minkä myötä palataan peruskysymyksiin toimintatavoista, tehtävistä, vastuista, vuorovaikutuksesta ja erityisesti siitä, kuinka leadership toteutuu ja muodostuu yhteiseksi tekemiseksi (Ropo, Eriksson, Sauer, Lehtimäki, Keso, Pietiläinen \& Koivunen 2005).

Verme-työskentelyssä nostetaan vertaisuuden tunnustaminen luottamuksen ja avoimen, "herruudesta vapaan" dialogisen suhteen rakentumisen edellytyksiksi. Toisen tunnustaminen auttaa samalla pääsemään kiinni defensseihin, organisaatiokäyttäytymisen dysfunktioihin ja Honnethin (1995, 160-170) mukaan sosiaalisten konfliktien eettisten ja moraalisten kysymysten käsittelyyn, jotka usein koskevat asymmetrisia valtasuhteita.

Verme ei ole johtamisteoria, eikä verme-työskentely edes tässä tapauksessa perustu yhteen tiettyyn johtamisen malliin vaan toimintatapaan, jossa vertaisuuden tunnustus on keskeinen periaate. Prosessissa osallistuja joutuu väistämättä erilaisiin dialogisiin rooleihin ja positioihin, jotka toimivat tunnustamisen performaatioina. Verme-koulutus vertaisuustyöskentelynä ja kontekstina kietoo roolien ottamisen, oman orientaation tai tyylin hakemisen, esimiehenä kehittymisen ja tässä tapauksessa sovelluskontekstinsa tapahtumia itseensä. Osallistuja joutuu ja pääsee toteuttamaan vertaistyöskentelyä työssään, omassa päällikkökäytännössään.

Oppiminen viedään osittain elimelliseksi osaksi osallistujan omaa työtä, vaikka koulutuksessa pidättäydytään antamasta suoranaisia johtamiskäsitteistä johdettuja neuvoja. Tutkimuksemme pohjana oleva verme-prosessi kehittyi esimiestuen muutoksen tuesta esimiestyön kehittämiseen muun muassa siten, että päälliköt ottivat käyttöön tiimeissään ja yksiköissään verme-koulutuksessa käytettyä ryhmä- ja henkilöohjausta (guidance counselling). 
Tutkimustehtävien kautta oma esimiestyö asettui jälkikäteisen reflektion ja koulutusryhmässä jakamisen kohteeksi, mistä kukin osallistuja palautti itselleen tarpeellisia asioita työhönsä. Katsomme vermekoulutukseen liittyvän prosessin vievän tehokkaasti johtamisoppimista työyhteisön yhteiseksi tekemiseksi ja siten jaetuksi asiantuntijatyön pääomaksi (ks. Raelin 2011, 145). Suoranaista ekonomisuutta voimme perustella sillä, että sekä epäviralliset eli non-formaalit että informaalit eli arkioppimisen, kuten päällikkötyön, arjessa tapahtuvat oppimisen muodot nousevat resursseiksi verme-koulutuksen ja johtamisen yhdistelmässä (ks. myös Heikkinen \& Tynjälä 2012).

\section{AINEISTO JA ANALYYSIMENETELMÄT}

Kuvaamme aineistoamme vielä toimintakontekstinsa ja pedagogisen otteensa kautta, jolloin tulee ymmärrettäväksi, millaisissa puitteissa esimerkiksi yksittäiset tutkimustehtävät ovat muotoutuneet. Verme-työskentely itsessään vaikuttaa johtajuuden hakemisen tapaan ja käsityksiin johtamisesta, koska se tässä tapauksessa pyrkii vertaisuuden rakentamiseen. Vermetyöskentelymme pedagoginen ote pohjaa hajautetun kognition ja jaetun asiantuntijuuden (Bereiter 2002; Parviainen 2006) sekä tutkivan oppimisen ja käytäntöyhteisön (Hakkarainen \& Paavola 2006; Wenger 1998) näkemyksiin. Professorit Hannu L. T. Heikkinen ja Päivi Tynjälä (2012) ovat korostaneet niin sanottua integratiivista pedagogiikkaa, joka yhdistää koulutuksen, työn ja teorian. Molemmat orientaatiot johtavat yhteiseen toimintaan usealla tavalla.

Oma toimintamme on pedagogiikkaa, jossa dialogisuus on enemmän kuin ammatillista puhetta tai kielellinen suhde. Verme-työskentelyä koskevien kysymysten ja kriittisen keskustelun kautta muotoutuu samalla mallia siitä, kuinka koulutuksessamme toimitaan, millainen pedagoginen otteemme on ja kuinka tarvitsemme ja kestämme kriittistä argumentaatiota asioiden etenemiseksi. Vastakkaiset ja toisten käsityksiä arvioivat argumentit toivat koulutuksessamme nopeassa syklissä esille ne asiat, jotka oman organisaation muutosprosessissa ovat oleellisia, ongelmallisia tai hyvin toimivia tai jotka työntekijät muutoin kokevat omiksi sisäisiksi ristiriidoikseen (vrt. Nikkola \& Harni 2015).

Näin myös johtamisen ja päälikkötyön kehittämisen kohteet paikantuivat melko vaivattomasti ja tarkentuivat prosessin myötä. Reflektiivinen keskustelu on muutostilanteessa tarpeen (Gray 2007), ja pintapositiivisten mahdollisuuksien sijaan käsittelimme usein kriittisiä tekijöitä, koska ristiriidat ja säröt ovat tunnetusti suomalaisen kognitiivisen pedagogiikan mukaan motivaation lähtökohtia.

Empiirinen aineistomme koostuu koulutusjaksojen materiaaleista, keskusteluista ja harjoituksista sekä tutkimustehtävien aineistoista, jotka nousevat päälliköiden johtamien ryhmien tapahtumista ja kokemuksista. Ohjelmassamme kukin neljästä tutkimustehtävästä noudattaa seuraavaa syklisesti syvenevää kehää:

1. tiedonhankinta lukemalla, havainnoimalla, neuvottelemalla tai haastattelemalla

2. oman käsityksen ulkoistaminen

3. toisille jakaminen keskustellen tai näyttämällä videointia, näyttelemällä (role playing) lähijaksolla 4. vertaispalautteen vastaanottaminen ja arviointi 5. palautteen saaminen koulutusohjelman vetäjiltä

6. palautteen vieminen takaisin omaan työhön ja verme-ryhmään neuvotellen ja kokeillen esimerkiksi ryhmämenetelmillä

7. jatkuva reflektointi blogin tai oppimispäiväkirjan muodossa

8. yhteen vetäen eri asioita ja omaa ymmärrystä esimerkiksi metaforilla (vrt. Choy 2009).

Emme erikseen keränneet aineistoa, haastatelleet tai tehneet kirjallisia kyselyjä artikkeliamme varten. Verme-koulutuksen aikaisista materiaaleista olemme nostaneet esille artikkelin kysymysten kannalta keskeisimmät tutkimustehtävät, eli organisaation tilaa erittelevät ja omaa verme-prosessia arvioivat tehtävät. Näistä oletimme saavamme vastauksia kysymyksiimme vertaisuuden tunnustamisesta. Hegeliläinen tunnustamisen käsite on noussut vasta keskustelujemme, hahmotustemme ja kirjallisuuden kautta näkökulmaksi vertaisuuden ja päällikkötyön tulkinnan problematiikkaan. 
Käytimme aineiston käsittelyn ja tulkinnan metodina englantilaisen kulttuuritutkijan Griselda Pollockin kehittämää lähiluentaa. Se on aineistolähtöinen käytäntö, jossa on tärkeää kiinnittää huomiota sekä siihen, mitä sanotaan, mutta kriittisesti myös siihen, mitä jätetään sanomatta (ks. Vänskä 2006, 63; ks. myös Silverman 2008). Metodia tutkineen Annamari Vänskän mukaan lähilukemista määrittää hidas ja perehtyvä ote materiaaliin, mikä vaatii lukijalta ja tulkitsijalta "sellaista teoreettista ja historiallista tietoa, jonka kautta yksityiskohdat alkavat puhua” (Vänskä 2006, 15).

Lähiluenta sopii mielestämme aineistoon, jonka tukena on oma noin yhdeksän kuukauden tuntemuksemme osallistujaryhmästä ja heidän orientaatioistaan. Hyvän ryhmätuntemuksen perusteella pystymme nyanssien varassa yhdistämään tehtävissä esille tulevat ilmaisut ja henkilön muun orientaation yhteen toistensa kanssa. Näin emme ole ainoastaan tehtäväilmaisujen, sanojen tai lauseilla esiin tuotujen ajatusten varassa, vaan ilmaisut tulevat henkilön toiminnan ja kontekstin tuntemuksen kautta luotettaviksi. Samalla ylitetään usein diskurssianalyyseille kriittisen puhekeskeisyyden, verbosentrismin, sekä kysely-haastattelu-aineistoille perustuvan epäautenttisen aineiston ongelma (Silverman 2008; Sampson 1998).

Artikkelimme aineisto on fokusoitu kahden kirjallisen tehtävän tuotoksiin verme-koulutuksen aikana. Sen analyysikokeilut ovat johtaneet useisiin kontribuutioihin, joissa verme-työskentelyn tutkimustehtävien tekstit, muu kirjallinen materiaali, visualisoinnit, verkkoalustojen keskustelut, videonauhoitukset ja valokuvat ovat toimineet sekä virikkeinä että evidensseinä.

Aineistossamme kysymys vertaisuuden tunnustamisen onnistumisesta tuo esille kolme erilaista ja neljännen potentiaalisen - orientaatiota, joihin luomme lyhyen katsauksen. Johtajaksi tai päälliköksi ei kasveta yhden tietyn formaatin tai prosessin mukaisesti. Kun itse organisaatio on muutoksessa ja etsii toimintatapojaan, silloin kun on periaatteessa useita vaihtoehtoja orientaation ottamiseksi, silloin kun esimies tai -nainen on hyvinkin erilaisten työntekijöiden ja asiantuntijaryhmien johtaja ja silloin kun sattuma johtaa juuri siihen kohtaan omaa elämäntilannetta, työtä ja työyhteisön prosessia, ei johtajan ote tiivisty yhdeksi mahdolliseksi orientaatioksi. Toiseksi aineistostamme nousee esille verme-johtamisen koetinkiveksi kutsumamme tapahtumien sarja, jonka perusteella on mahdollista analysoida ja tulkita uuden johtamisotteen kestävyyttä hankalissa olosuhteissa, tässä tapauksessa organisaatioiden yhteistoimintatilanteessa.

\section{TULOKSET - MITEN VERTAISUUDEN TUNNUSTAMINEN ONNISTUU PÄÄLLIKÖIDEN TYÖSSÄ}

Hegeliläisen logiikan ja käytännön legitiimin dialektiikan mukaisesti päälliköllä on periaatteessa performatiivinen valta, jo lähtökohtaisesti tunnustajan positio itse työssä. Esimerkeistämme on havaittavissa, että tunnustuksen logiikka ei toimi hegeliläisittäin yksisuuntaisesti ylhäältä alas vaan molemminpuolisesti päällikkö-työntekijäsuhteessa. Emme puutu prosessin "jalostavaan" vaikutukseen sen tarkemmin, mutta vastarintojen ja ristiriitojen kautta etenevä kehityskulku näyttää olevan normaali ja käytännöllisesti tuottoisa tie uudenlaiseen johtajuuteen. Millaisiin vertaisuutta tunnustaviin tuloksiin verme-koulutuksen prosessit johtivat?

\section{Päällikkö ja työntekijät tunnustavat toisensa}

Vaikka vaikeudet saattavat johtaa prosessin parhaaseen lopputulokseen, molemminpuolinen myönteinen orientaatio vertaisuuteen on päälliköiden tuottamien tutkimustehtävien mukaan joka tapauksessa hyvä lähtökohta. Vertaisuuden käsittämistä ja omaksumista aineistomme auttoi oman asiantuntijatyön periaatteiden avaaminen ja vertaisuuden pitäminen myös johtamisen ytimenä. Johtamisorientaatio saa lähtökohtansa näin itse työn tieto-opillisista kysymyksistä, eikä sille tarvitse hakea perusteita toiminnalle abstrakteista asioista tai johtamisen muodollisuuksista. Vertaisuuden käsitteen tarkastelu yhdessä auttoi tulkitsemaan uutta johtamisorientaatiota. 


\section{VAKIINTUNEET ESIMIES-}

\section{ALAISROOLIT VOIVAT}

\section{JARRUTTAA TASAVERTAISTA}

TYÖSKENTELYÄ.

"Avasimme hieman vertaisuutta ja totesimme, että olemme kaikki yhtä tärkeässä roolissa nuorten kasvattajina ja luotettavina aikuisina. Tämä vertaisuus mahdollistaa sen, että kaikki voimme omasta näkökulmasta tuoda esille ajatuksia ilman sosiaalisen statuksen tai tittelin asettamaa painoarvoa." (Otto, 2)

"Puhuimme myös auki sitä, mitä vertaisuus meidän kesken tarkoittaa [--]. Se tuntui heistä hyvin luontevalta, että olemme vermeessä työtovereina - emme esimiehinä ja alaisina." (Sakari, 2)

Päällikkö ja työntekijät tunnustavat toisensa -orientaatioon asettuu suurin osa aineistomme päälliköistä. Heidän yksiköissään käsiteltiin myös vaikeat asiat yhteisesti rakentaen toiminnalle jatkuvuutta asiantuntijatyön tekemisen ehdoin. Muun muassa johtamisoppimisen teoreetikko David Gray pitää uudenlaisia yhteisöllisiä reflektiivisiä työtapoja ja menetelmiä sekä kriittistä osallistumista etenkin muutostilanteissa välttämättöminä. Niiden avulla sekä haastetaan vanhat normatiiviset käsitykset että luodaan osallistavien menetelmien kautta uusia toimintatapoja (Gray 2007). Erityisesti organisaatiosta laskeutuvat ongelmat saatiin päälliköiden mukaan pidettyä rajallisina rakentamalla orientaatio yhteiselle työn kehittämiselle.

Tehtäväänsä noviisina nimetyt päälliköt saattoivat luontevasti helpottaa omaa tehtäväänsä toisten kanssa työskentelyllä, keskustelemalla ja ratkaisemalla johtamista koskevia asioita yhdessä. Työiältään työntekijät olivat keskimääräistä nuorempia.

Gray (2007, 497-498) korostaa etenkin sitä, että kriittisen reflektion otteeseen on kouluttauduttava ja sitä on tuettava, koska muutoin se saattaa johtaa epäilyihin, ahdistuksen tunteisiin tai identiteetin tunteen menetykseen (ks. myös Contu 2008). Ilman verme-koulutuksen orientaatiota päälliköt tuskin olisivat ottaneet vertaisuusajatusta pohdinnan kohteeksi tai näkökulmaksi omassa työssään. Tuoreiden päälliköiden ja nuorempien työntekijöiden näytti olevan helpompi omaksua uusia orientaatioita muutostilanteissa kuin kokeneiden ja etenkin vakiintuneissa rakenteissa yksin muutoksia yrittävien.

\section{Päällikkö pyrkii tunnustamaan, työntekijät vastustavat}

Vertaisuus ei ole itsestäänselvyys. Päälliköiden uusi orientaatio ei osoittautunut työntekijöille helposti omaksuttavaksi, minkä yksi osallistuja määritteli vuosikymmenten aikana piintyneeksi "hierarkiatahraksi" (Joona, 4, 1). Molemmin puolin totutut esimies-alaisroolit voivat olla hankalin jarru tasavertaisen työskentelyn edistämisessä. Perinteiset johtajakäsitykset ovat tyypillisesti yksilöiviä, persoonallisia ominaisuuksia, kykyjä ja hierarkkisia positioita korostavia, puhdistettuina kulttuurista tai muutoksista (Crevani, Lindgren \& Packendorff 2010).

Työyhteisönormit, palkkaus ja mikrokäytännöt tukevat roolien ja tehtävien eriytymistä voimakkaasti edelleen. Niin sanotun herooisen johtajuuden käsityksestä (Crevani, Lindgren \& Packendorff 2007) on vaikea luopua etenkin silloin, kun päälliköiden palkkaukseen ja palkitsemiseen liitetään vahvoja suoritus-, tavoite- ja kilpailuelementtejä (ks. esim. Luthans \& Stajkovic 2017). Työntekijät odottavat tällöin johtajalta vahvaa toimintaa, jolloin työntekijä itse voi pysytellä passiivisessa roolissa. Kaksi verme-koulutukseen osallistunutta päällikköä koki, että vanhat työntekijät välttelivät yhteiseen työskentelyyn sitoutumista vedoten päallikön perinteiseen vastuunkantajarooliin.

"Kutsuin heidät vermeryhmään [--] eli tavoitteeksi asetin tasavertaisen yhteistyön toteutumisen. Mutta kuormaa ja ratkomattomia asioita oli kertynyt vuosien varrella liikaa, jäsenet eivät suostuneet heittäytymään ja tarkastelemaan työtapaansa eikä kohtamaan avoimesti." (Beata, 4)

Pidättäytyminen oli samalla työntekijöiltä vallankäyttöä, jota yleensä käsitellään virheellisesti vain vasta- 
rintana. Syinä saattavat kuitenkin olla uusien vastuiden ja lisääntyvän työmäärän välttäminen, kuten Beata ilmaisee edellä, tai järkevä "kognitiivinen editointi”, joka on tervettä epäröintiä tuntemattoman tilanteen tai asian edessä. Se yleensä ratkeaa kognitiivisin keinoin, tietoa lisäämällä ja käsittelemällä.

Näissä koulutusalayksiköissä työntekijöiden työhistoriat olivat pitkiä ja koulutusalat vakiintuneita. Opettajat osoittivat vahvaa oman työn yksilöllistä hallintaa ja pitivät asiantuntijuutensa rajoista kiinni myös suhteessa saman yksikön toisiin opettajiin. Yksilöllinen työote ja oman "tontin" hoitaminen olivat vakiintuneet toimintatavaksi. Heidän perinteisellä työmoraalillaan perusteltu sankariotteensa omaan työhönsä siirtyi samanlaiseksi vaatimukseksi päälliköille.

Toimijuuden siirtymistä uudelle alueelle, jaettuun ja osallistavaan vertaisjohtamiseen oli työkuormituksen ja vakiintuneiden työtapojen vuoksi vaikea muuttaa. (vrt. myös Eteläpelto ym. 2011) Työntekijöille oli taloudellista huolehtia mahdollisimman hyvin vain "omasta tontistaan".

Pyrkimyksessään uuteen orientaatioon omassa työyksikössään päällikkö jää yksin ja yksinäiseksi muutokseen pyrkijäksi, jonka oma status ja maine työntekijöiden perinteisissä johtajuusodotuksissa laskee. Tulkitsemme, että muutoksessa koko organisaation tulisi erilaisia johtamisstrategioita käyttäen luoda, informoida ja pitää selkeästi yllä yhteinen tavoite ja arvopohja (ks. Ståhle, Sotarauta \& Pöyhönen. 2004; Gray 2007), tässä tapauksessa vertaisuusajattelu.

\section{Molemmat pitäytyvät perinteisissä päällikkö-alainen-positioissaan}

Tämä orientaatio näkyi toiminnassa selkeästi ainoastaan yhdessä tapauksessa, jossa henkilö oli toiminut aikaisemmin päällikkötehtävässä eikä nähnyt tarvetta muuttaa toimintatapaansa uudessa organisaatiossa. Tehtävien ja keskustelujen perusteella hän kuitenkin toimi hyvin työ- ja toimintakeskeisesti omien työntekijöidensä kanssa. Varsinaiset päällikkötehtävät olivat täysin erillään yhteisötoiminnasta, ja keskeinen ongelma oli yksikön taloudellisen menestyksen turvaaminen. Ongelmaa ratkaistiin yhteisillä talkoilla, joissa tehtiin yksikön toimialan mahdollistamia konkreettisia tuotteita.

Tämä päälikkö pidättäytyi aktiivisesti käyttämästä myöskään mitään vertaisuutta tai vermeä koskevia termejä työssään. Perinteisissä rooleissa pitäytymisen tilanteessa ei näytä kuitenkaan olevan tarvetta ottaa päällikön työskentelyotetta erityisen puheen kohteeksi, koska pällikön ja työntekijöiden funktiot ovat erillään ja päällikön sanoin "päällikkö johtaa". Organisaation muutostilanteessa sama päälikkö kuvasi esimiestyötään "tulipalojen sammuttamiseksi" ja sanoi työskentelyn tapahtuvan "sekavissa tunnelmissa" (Ilona, 4).

Kun organisaatiossa ei toteuteta vahvaa ylhältä johtamista, ja muutostilanne etenee antaa mennä -tyylillä, päälliköiden toiminnalleen saama tunnustus on niukkaa. Onpa muutostilanteessa tuloksena sitten mikä hyvänsä johtamisen tapa, informaalin "paikallisen pörinän" ja tavoitteellisen formaalin arvokeskustelun merkitys korostuu työyhteisössä (ks. Ståhle ym. 2004).

Organisaation muutostilanteissa keskusteluiden monimuotoisuutta korostetaan kaikissa uudemmissa johtamisnäkemyksissä (Crevani ym. 2010; Gray 2007; Raelin 2011; Juuti 2018). Tutkimassamme organisaatiomuutoksessa informointi läpi organisaation ja uusien päälliköiden tukeminen rakentuivat suurelta osin heidän keskinäisenä toimintanaan vermekoulutuksen aikana. Päällikkötyön kehittäminen jäi päällikköryhmän sisäiseksi asiaksi.

\section{Henkilöstö on valmis muutokseen, mutta päällikkö vastustaa}

Aineistomme myötä emme päässeet analysoimaan neljättä mahdollista orientaatiota. Se koskee tilanteita, joissa henkilöstö olisi ollut halukas muuttamaan orientaatiota mutta päällikkö olisi vastustanut. Vain jotkut päälliköt osallistuivat koulutukseen, emmekä tutkineet koko organisaation esimies-työntekijäsuhteita.

Työntekijöiden puolelta "tunnustukseton" asetelma ja tuntemus edustavat yleisintä tilannetta (ks. Juuti 2018). Tunnustukseton asetelma saattaa koskettaa myös itse päälliköitä, jotka ovat samankaltaisessa "alaisen" positiossa suhteessa ylempään organisaatioonsa, josta sisältöä koskevan tunnustuksen 
saaminen on "ajokoiramaisten" yksilösuoritusten varassa muutoinkin kuin ulkonäön osalta (Tienari \& Meriläinen 2016).

Päälikkö hakee joka tapauksessa tunnustuksen ja legitimaation itselleen jostakin suunnasta. Johtamista paljon tutkineen professori Pauli Juutin (2018, 42 43) mukaan päälikkö hakee sen tyypillisesti organisaation johtoportaasta, jolle osoitetaan lojaalisuutta.

\section{ORGANISAATIOMYLLERRYS}

\section{- TUNNUSTUKSEN KOETINKIVI}

Oma organisaatio aiheutti kuitenkin suurimman muutoksen useimpien päälliköiden jo vähitellen omaksumaan johtamisen orientaatioon. Organisaation ilmoittamat yhteistoiminta- eli yt-neuvottelut tulivat heillekin yllätyksenä, ja sen seurauksena uutta työotetta kokeilevat päälliköt kokivat ratkaisevan muutoksen työntekijöidensä asenteissa. Monissa tapauksissa päälliköiden tavanomaista läheisempi johtajarooli kyseenalaistettiin.

Yhteistoimintaneuvottelut sysäsivät myös erilaisilla ennakko-orientaatioilla työskennelleet erottautumaan toisistaan. Useimmat pääliköt ratkaisivat kriittisen tilanteen jatkamalla yhteistoiminnallista linjaa työntekijöidensä kanssa, koska sen muotoa oli totuttu käyttämään kaikissa johtamiskysymyksissä. Muutama luovutti välittäjän roolinsa ja antautui tietynlaiseen antaa mennä -päällikön rooliin. Kriisiytyneessä tilanteessa päällikkö siis palaa entiseen ylhäältä alas -päällikkörooliin, jotta saavutetaan edes oman position tunnustus sieltä, koska se jää puutteelliseksi omalta henkilöstöltä.

"Olosuhteet ovat katkerasti murtaneet kokonaista roolia kahdeksi erilliseksi lähiesimiehen ja vermeohjaajan rooliksi. Kaksi roolia samassa naamassa on kaksinaamaisuutta ja kaksinaama ei voi vetää vermeryhmää aidosti vertaisena, vaikka tahtotaso olisi ylätasolla." (Joona, 4)

"Alussa vermeohjaajan ja esimiehen rooli sopi hyvin [--] sitten kun tuli irtisanomiset, niin esimiestä ei enää pidetty vertaisena [--] luottamus [verme] vetäjään oli mennyt, koska edusti "pahaa organisaatiota”" (Hanna, 4, 1)
Päällikkö ajautui ristiriitaisia vaateita tuottavassa tilanteessa eettiseen kysymykseen, "[--] vertaisuus velvoittaa vertaisuuteen - sitä ei voi leikkiä." (Aura, 4, 3). Petetyksi tulemisen tuntemus oli useilla koulutuksen aikainen ensireaktio, jonka syitä ajauduttiin ensiksi hakemaan itsestä, "[--] tällaisessa tilanteessa [yt-neuvottelut] minä olen kääntynyt sisäänpäin” (Jatta, 4, 2). Useimmat niistä, jotka olivat havainneet toiminnassaan uusia vahvuuksia, jatkoivat alkureaktioiden jälkeen vermetyöskentelyä oman yksikkönsä työntekijöiden kanssa.

"Kaikki tapahtunut [yt-menettelyt] on jollain tavalla rikkonut koko organisaatiomme kulttuurin [--], toisaalta [--] yhteisössä on pakko muuttaa "me on aina tehty näin"-ajattelua" (Otto, 4, 2)

"Uuden organisaation rakentaminen vaati yt-neuvottelut, jotka hidastivat monta käynnissä olevaa prosessia [--]. Ylemmän johdon kaikki aika ja energia meni yt-tilanteen hoitamiseen ja kehittämistyö pysähtyi. Oppilaitoksen arki kuitenkin jatkoi kulkuaan ja arjen käytännön ongelmien ratkaisu jäi väliportaan esimiehille eli meille uusille päälliköille. [--] verme-koulutus mahdollisti meille syvällisen tutustumisen uuteen työyhteisöön." (Aura, 4, 2-3)

Yt-neuvottelut olivat koetinkivi, joka jakoi päälliköt kahteen pääleiriin jatko-orientaatioissaan. Joidenkin asiallinen dialogiyhteys ylöspäin katkesi, ja he keskittyivät työskentelemään oman henkilöstönsä kanssa välttääkseen resurssiensa haaskaamista turhaan byrokratiaan. Selkeä vähemmistö ikään kuin luovutti uudenlaisen johtamisroolinsa vahvistamisen, ja enemmistö jatkoi yhdessä työskentelyä henkilöstönsä kanssa. Molemmissa tilanteissa koettiin epävarmuutta työn tulevaisuudesta, ja molemmissa ratkaisuissa näkyi lojaliteetti ensisijaisesti omiin kollegoihin ja samaa työtä tekeviin, ei organisaation johtoon. Tämä on tyypillistä työyhteisön epävarmuustilanteissa (Pesonen \& Eriksson 2011, 183).

Epävarmuus johtaa pelkoon, ja pelko puolestaan johtaa tuntemukseen huonosta johtamisesta (Luomanen 2009). Samalla ratkaisut ovat työkuormituksen kannalta järkeviä, jolloin työntekijöiden ja päällikön omat resurssit voidaan pysyttää ammatillisessa toiminnassa. Näin vältytään organisaation tunnustuksen 
turhasta hakemisesta, ja yhteisyys säilyy omassa yksikössä. Kriisitilanteissa tunnustus saadaan siten omasta viiteryhmästä ja sulkeutumalla vain omaan työhön, mikäli omat sisäistetyt pyrkimykset ja ulkoiset pakot joutuvat ristiriitaan. Verme-työskentelyssään onnistuneet jatkoivat kehittämistä ja suunnitelmien yhteistä tekemistä jopa henkilövähennysten varalle.

Aineiston lähiluku edellyttää vähitellen etenevää ja syvenevää tekstien tai muun materiaalin tulkintaa. Kohteena olleet tekstit rajautuivat koulutukseen sisältyneiden kahden tutkimustehtävän analyysiin ja tulkintaan.

Lähiluvun luotettavuuden takeena pidämme monitahoista tutkimuskohteen ja kontekstien tuntemusta, keskinäisiä keskustelujamme ja eri vaiheissa kontribuutioista saamiamme palautteita. Tutkimuksemme kysymyksenasettelu on samanaikaisesti muuttunut yhä fokusoidummaksi: miten päälliköt onnistuivat vertaisuusajattelun soveltamisessa työssään ja mitkä asiat organisaation muutostilanteessa nousevat keskeisiksi ongelmiksi? Tulokset eivät toimi määrällisinä todisteina vertaisuusajattelun toimivuudesta, mutta pystyimne tavoittamaan tällä metodilla työskennellen päällikkö-alaissuhteen erilaiset perusorientaatiot ja niihin liittyvät kysymykset vertaisuuden toteutumisesta.

\section{POHDINTA}

Hegeliläisen tunnustuksen käsitteen periaatteet toteutuvat ensisijaisesti yleishumaanina työntekijän eettisen, ihmisenä olemisen ja osallisuuden kunnioittamisena. Olemme perustelleet, että jaetun asiantuntijuuden ja johtamisen edellytys on puolestaan tunnustetuksi tuleminen, vertaisuuden tunnustus toiminnassa. Vertaisuusperiaatteen avoin käsittely omassa johdettavassa yksikössä näyttäisi olevan onnistumisen edellytys jaetun johtamisen jatkuvuudelle. Jos on tehnyt vertaisten kanssa keskustellen ja tutkien tietoisen valinnan sitoutua jaettuun johtamiseen, on joutunut kriittisesti erittelemään itselleen ja muulle yhteisölle orientaationsa perustan. Tähän orientaatioon tukeutuen pystyy käsittelemään myös organisaatiokriisejä.

Vapaaehtoisuus ei muuta vahvoja hierarkkisia johtamisen tiedostamattomia periaatteita, vaan kriittiset organisaatiomuutokset useimmiten palauttavat vallinneen tilanteen. Hierarkkiset rakenteet - huolimatta yrityksistä purkaa niitä - näyttävät puolestaan organisaatiokriisissä johtavan siihen, että eri ryhmät tai yksilöt kääntyvät sisäänpäin, jolloin jaetun johtamisen monet edut, ennen kaikkea yhä välttämättömämpi yhteistoiminta ja -kehittely, jäävät hyödyntämättä.

Useimmissa johtamisen teorioissa korkeata motivaatiota pidetään myös taloudellisesti tuloksellisena. Muun muassa Grayn (2007) vaatimus kriittisten metodien käytöstä johtajaksi kouluttautumisessa ei kuitenkaan näytä yleisesti kestävän, kun organisaatio itse kriisiytyy tai saatetaan kriisiytymään. Tutkimuksessamme se todentui pääasiassa pääliköiden muutoskriisinä, jossa yt-tilanne oli erityinen ja poikkeuksellinen ratkaiseva tekijä. Hegeliläistä "tunnustuksen kamppailua" työntekijä joutuu joka tapauksessa tekemään itseluottamuksensa, -tuntemuksensa ja -arvostuksensa kanssa jokaisessa yhteisössä (Huttunen 2003). Voimme kysyä, onko tunnustuksen anominen tai itsensä alistaminen uudessa työssä se motivaattori, joka "orjaa” liikuttaa - eivätkä niinkään "herran" näkyvät tunnustuksen performaatiot (ks. Kotter 1996; Suominen 2013; Jokinen \& Venäläinen 2015)?

Aineistomme perusteella päällikkö hakee tunnustuksen ja legitimiteetin jostakin suunnasta organisaatiossaan - ja verme-koulutuksen orientoimana ensisijaisesti omilta työntekijöiltään. Periaatteessa henkilöstönsä kanssa johtamista jakava päällikkö on kahden tulen välissä organisaation muutoksissa, jotka edellyttävät henkilöstöjärjestelyitä. Etenkin kriisitilanteet näyttäytyvät sopivana koetinkivenä vertaisuuden ja jaetun johtamisen toteutumiselle organisaatiossa. Tulosten perusteella ongelmallisimmaksi tunnustuksen kohteeksi ja kysymykseksi nousee työntekijöiden asia- ja johtamisosaamisen havaitseminen, ymmärtäminen ja tunnustaminen johtamisen perustana myös kriittisten tilanteiden ratkaisemiseksi.

Tutkimuksemme kohdeorganisaatioiden ylin johto rajasi päällikkötason työntekijöineen yt-neuvottelupäätösprosessista - manageriaalinen ja henkilöjohtaminen eriytyivät hierarkkisesti toisistaan yt-tilanteessa. Ylemmän organisaation taholta työntekijöiden asiantuntijuuden ja vertaisuuden tunnus- 


\section{VERTAISUUDEN}

\section{TUNNUSTUKSEN K ̈̈YT ÄNTÖJ $\ddot{A}$ \\ KANNATTAISI SISÄLLYTT $\ddot{A}$}

\section{JOHTAMISK OULUTUKSIIN.}

tuksen rajat tulivat siten vastaan taloudellisin perustein tehdyissä henkilöstöjärjestelyissä. Rajat määritti talouseetos, joka oikeuttaa epävarmuuden ylläpitämiseen ja tunnustuksen kaikkien tasojen rikkomiseen. Uhkakuvat ja epätietoisuus tulevaisuudesta käänsivät samoin nopeasti yksiköiden yhteisen johtamiskehittämisen epävarmuudeksi, joka johtaa pelolla johtamiseen ja siten "huonoksi johtamiseksi" (Juuti 2018).

Informaation puute muiden päalliköiden kesken ja suhteessa organisaation johtoon ei ollut aineistomme mukaan eduksi vertaisuusperiaatteelle. Pikemminkin työntekijät pyrkivät hakemaan turvaa toisistaan ja kohdistamaan lojaliteettinsa kollegoihinsa, eivät organisaation arvoihin.

Jaetulle ja asiantuntijuuden tunnustamiseen perustuvalle johtamiselle on useita taloudellisia perusteita, jotka näyttäytyvät ainakin heikkoina signaaleina aineistomme lähiluvussa. Työn taloudelliset näkökulmat olivat tunnistettavissa useiden päälliköiden tilanteissa, joissa he hallitsivat yhdessä työntekijöidensä kanssa kriisitilannetta ja perustelivat uutta johtamisotettaan sillä, että oli joka tapauksessa välttämätöntä kehittää toimintaa ja katsoa eteenpäin. Sosiaalisten pääomien käyttö tuottaa taloudellisia etuja monella organisaation toiminnan tasolla (Putnam 2000).

Työryhmän tai asiantuntijatiimin johtaminen ulkopuolelta on pinnallisempaa kuin sen johtaminen sisältä käsin. Amerikkalainen johtamisen professori Joseph Raelin (2011) korostaa varsinkin sitä, että samalla kaapataan yhdessä oppiminen takaisin asiantuntijatyön kehittämiseen ja taloudelliseksi pääomaksi, koska muutosta voidaan toteuttaa vain yhteisen oppimisen ja reflektoinnin varassa (ks. myös Gray 2007). Verme-koulutus sisältää myönteisen käsityksen työntekijöiden asiantuntijapotentiaaleista myös johtamisen ekonomian tarkastelussa.

Työn yksityistymisen seurauksena taloudelliset suhteet tunkeutuvat yhä selkeämmin yksityisen alueelle ja koko elämään (Arendt 2017), minkä vuoksi on erityisen tärkeää, millaisten tendenssien varassa työelämää ja "uutta työtä" kehitetään. Työelämän rappeuttavat ja kolonisoivat vaikutukset saattavat tuhota lopulta työn hegeliläisen sivistysfunktion, jolle kulttuuri rakentuu (vrt. Miettinen 2016).

Valtaa tutkineen ranskalaisfilosofin Michel Foucaultin (1988) kuvaamat kommunikaatiosuhteet voivat olla suuressa määrin suoran tai piiloisen vallankäytön välineitä ja teknologioita - myös tunnustus - henkilökohtaisessa vuorovaikutuksessa (vrt. myös Deleuze 2005). Sisäistettyä valtaa ja itsehallintaa pidetään juuri nietzscheläisen filosofian esittämänä kritiikkinä, koska sisäistetty velvollisuusja syyllisyysetiikka ajaa toteuttamaan myös orjuuttavaa vallantahtoa (ks. Deleuze 2005, 22; myös Harni 2015). Erilaisissa instituutioissa yleistyvä vertaistoiminta joutuu jatkamaan myös tämän dilemman parissa. Koulutuksessamme monet päälliköt ratkaisivat dilemmaa vetäytymällä omien työntekijöidensä kanssa sopivasti erilleen ylhäältä tulevista impulsseista sekä keskustelemalla enemmän toisten päälliköiden kanssa.

Kritiikki huomioiden vertaisuuden tunnustuksen käytäntöjä kannattaisi sisällyttää johtamiskoulutuksiin, sillä niiden kriittisellä reflektoinnilla voisi olla myönteinen vaikutus esimies-työntekijä-alainen-hierarkiasuhteen tarkastelussa. Hegeliläisellä tunnustuksen käsitteellä on kriittistä potentiaalia myös työelämäanalyyseissa ensinnäkin vanhojen positioiden, työnjaon ja hierarkian säilyessä, toiseksi tunnustuksen muuttuessa yksilöasiantuntijatyön ulkoiseksi palkitsemiseksi ja kolmanneksi tunnustuksen muuttuessa liukkaiksi organisaatiorituaaleiksi.

Vertaisuuden tunnustamiseen perustuvaan johtamistapaan kasvaminen on perinteitä rikkovaa ja kriittistä. Siksi se kohtaa monia johtamisen institutionaalisia ongelmia. Yhteinen koulutusprosessi säröineen luo edellytyksiä kokeilla ja tuetusti vakiinnuttaa uudenlaista, jaettua johtamistapaa. Asiantuntijatyössä muutosten ohjaaminen johtamiskäskyillä näyttää tuottavan vain yhteisöllistä hämmennystä.

Aineistossamme jää tutkimatta, kuinka päälliköt 
ovat pystyneet jatkamaan omaksumiaan johtamisorientaatioita. Talous ja työekonomia ovat nousseet esille monella tavalla tutkittavan organisaation ja yksilöiden muutostilanteissa. Kiinnostava teoreettinen jatkotutkimuksen kohde onkin nietzscheläiseen moraalisen ja taloudellisen vallanhalun käsitteeseen pohjautuva hegeliläisen tunnustuksen kritiikki.

Oletamme joka tapauksessa, että verme-koulutuksen malli soveltuu kokeiltavaksi tilanteisiin, joissa johtajia ja päälliköitä koulutetaan ensinnäkin rakentamaan uutta orientaatiota johtamiseen siirtymätilanteissa byrokraattisista organisaatioista uusiin muotoihin. Toiseksi se sopii tiimi- ja verkostomuotoisiin yhteisöihin, joissa asiantuntijoiden pitää yhdessä kehittää omaa työtään.

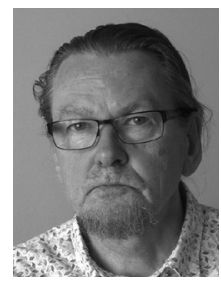

HEIKKI PASANEN

FT, yliopettaja, eläkkeellä

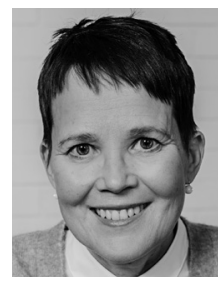

MERJA ALANKO-TURUNEN

FT, KTM, yliopettaja

Haaga-Helia Ammatillinen

opettajakorkeakoulu

LÄHTEET.

Alanko-Turunen, M. \& Pasanen, H. (2009). Connecting: Finnish Research on World of Work and Vocational Education. The 6th International Conference on Researching Work and Learning 28. June - 1. July 2009 at Roskilde University (RUC) Denmark. Proceedings (part 1 of 3), 338-349.

Alanko-Turunen, M. \& Pasanen, H. (2011). Innovating In-service Training of Vocational Teachers: Peer Group Mentoring (Verme) in Finland. The 7th International Conference on Researching Work and Learning Shanghai 4.-7.12.2011.

Alanko-Turunen, M. \& Pasanen, H. (2012). Verme ammatillisen opettajan tukena muutosten kentällä. Teoksessa Heikkinen, H., Jokinen H., Tynjälä, P. 2012. Osaaminen jakoon. Vertaisryhmämentorointi opetusalalla. Juva: PS-Kustannus, 173-187.

Alanko-Turunen, M. \& Pasanen, H. (2013). Peer-group Mentoring Making the Intricate Work of a Vocational Teacher Visible. The 8th International Conference on Researching Work and Learning Proceedings, Stirling, UK, June 19ul.

Arendt, H. (2017). Vita activa. Tampere: Vastapaino.

Bereiter, C. (2002). Education and Mind in the Knowledge Age. Mahwah, NJ: Lawrence Erlbaum Associates.

Choy, S. (2009). Transformational Learning in the Workplace. Journal of Transformative Education 7(1), 65-84.

Contu, A. (2008). 'Decaf Resistance: Misbehaviour, Desire and Cynicism in Liberal Workplaces. Communication Management Quarterly 21(3), 364-379.
Crevani, L., Lindgren,M. \& Packendorff, J. (2007). Shared leadership: A Postheroic Perspective on Leadership as a Collective Construction. International Journal of Leadership Studies 3(1), 40-67.

Crevani, L., Lindgren, M. \& Packendorff, J. (2010). Leadership, not Leaders: On the Study of Leadership as Practices and Interactions. Scandinavian Journal of Management 26 (1), 77-86.

Deleuze, G. (2005). Nietzsche ja filosofia. Helsinki: Summa.

Elmgren, H. (2015). Opettelua heikkousalueella - Giorgio Agamben ja oppimaan oppimisen kritiikki. Teoksessa Harni, E. (toim.) 2015. Kontrollikoulu. Jyväskylä: Kampus Kustannus, 137-151.

Eteläpelto, A., Heiskanen, T. \& Collin, K. (toim.) (2011). Valta ja toimijuus aikuiskasvatuksessa. Helsinki: Kansanvalistusseura \& Aikuiskasvatuksen Tutkimusseura.

Foucault, M. (1988). Technologies of the Self. Teoksessa Martin, L.H, Gutman, H. \& Hutton, P.H. (toim.) Technologies of the Self: A Seminar with Michel Foucault. Amherst: University of Massachusets Press, 16-49.

Gray, D.E. (2007). Facilitating Management Learning: Developing Critical Reflection through Reflective Tools. Management Learning 38 (5), 495-517.

Hakkarainen, K. \& Paavola, S. (2006). Kollektiivisen asiantuntijuuden mahdollisuuksia ja rajoituksia Kognitiotieteellinen näkökulma. Teoksessa Parviainen J. (toim.) Kollektiivinen asiantuntijuus. Tampere University Press, 214-272. 
Harni, E. (2015). Mielivaltaista kasvatusta, yrittäjyyskasvatusta. Teoksessa Brunila, K., Onnismaa, J. \& Pasanen, H. (toim.) Koko elämä töihin - koulutus tietokykykapitalismissa. Tampere: Vastapaino, 102-119.

Heikkinen, H. L. T., Jokinen H. \& Tynjälä, P. (2012). Osaaminen jakoon. Vertaisryhmämentorointi opetusalalla. Jyväskylä: PS-Kustannus.

Heikkinen, H. L. T. \& Tynjälä, P. (2012). Työssä oppimisen monet muodot. Teoksessa Heikkinen, H., Jokinen H. \& Tynjälä, P. (toim.) Osaaminen jakoon. Vertaisryhmämentorointi opetusalalla. Jyväskylä: PS-Kustannus, 17-25.

Heinilä H. \& Tapani A. (2011): “Enää ei olla kuin myyrät koloissaan, " Yhteisöllinen työskentely opettajien täydennyskoulutuksessa. Aikuiskasvatus 31 (1), 52-58.

Honneth, A. 1995. The Struggle for Recognition. The Moral Grammar of Social Conflicts. Cambridge, Mass.: The MIT Press.

Huttunen, R. (2003). Kommunikatiivinen opettaminen. Indoktrinaation kriittinen teoria. Jyväskylä: Minerva Kustannus Oy.

Huttunen, R. (2009). Indoctrination, Communicative Teaching and Recognition - Studies in Critical Theory and Democracy in Education. Joensuun yliopisto. Kasvatustieteiden tiedekunta: Yliopistopaino.

Huttunen, R. \& Heikkinen, H. (2004). Teaching and the Dialectic of Recognition. Pedagogy, Culture \& Society 12 (2), 163-174.

Jakonen, M. (2014). Uusi työ ja prekarisaatio: Työn muutosten vaikutukset suomalaiseen hyvinvointivaltioon ja poliittiseen järjestäytymiseen. Tiede ja edistys 39 (4), 287-320.

Jokinen, E. \& Venäläinen J. (toim.). (2015). Prekarisaatio ja affekti. Nykykulttuurin tutkimuskeskuksen julkaisuja 118. Jyväskylä: Jyväskylän yliopistopaino.

Julkunen, R. (2008). Uuden työn paradoksit. Keskusteluja 2000-luvun työprosess(e)ista. Tampere: Vastapaino.

Juuti, P. (2018). Huono johtaminen. Tuhon tieltä toimivaan työyhteisöön. Helsinki: Gaudeamus.

Kojève, A. (2012). Johdatus Hegelin lukemiseen. Helsinki: Tutkijaliitto.

Kotter, J. P. (1996). Leading Change. Boston: Harvard Business School Press.

Lazzarato, M. (2014). Velkaantunut ihminen. Helsinki: Tutkijaliitto.

Luomanen, J. (2009). Fear and Intimidation at Work. Research report. The Finnish Work Environment Fund.

Luthans, F. \& Stajkovic, A. (2017). The Impact of Recognition on Employee Performance: Theory, Research and Practice. Researchgate. https://www. researchgate.net/publication/228536942.

Miettinen, R. (2016). Sivistys kilpailuyhteiskunnassa - mitä annettavaa Hegelillä on tänään? Kasvatus \& Aika 10(3) 2016, 57-75.
Nikkola, T. \& Harni, E. (2015). Sisäistyneet ristiriidat, tunnetyö ja tietotyöläissubjektiviteetin rakentuminen. Aikuiskasvatus (35) 4, 244-253.

Parviainen, J. (2006). Kollektiivinen tiedonrakentaminen asiantuntijatyössä. Teoksessa Parviainen J. (toim.) Kollektiivinen asiantuntijuus. Tampere: Tampere University Press, 155-187.

Pesonen, S. \& Eriksson, M. (2011). Pelolla johtaminen työyhteisöissä. Teoksessa Eteläpelto, A., Heiskanen, T. \& Collin, K. (toim.) 2011. Valta ja toimijuus aikuiskasvatuksessa. Vantaa: Kansanvalistusseura ja Aikuiskasvatuksen tutkimusseura, 177-198.

Putnam, R. (2000). Bowling Alone: The Collapse and Revival of American Community. New York: Simon \& Schuster.

Raelin, J.A. (2003). Creating Leaderful Organizations: How to Bring out Leadership in Everyone. San Francisco, CA: Berrett-Koehler.

Raelin, J.A. (2011). The End of Managerial Control? Group \& Organization Management 36(2), 135-160.

Roman-Lagerspetz, S. (2016). Feministinen uskonnonfilosofia ja Hegelin tunnustusteoria. Uskonnonfilosofian pro gradu. Helsingin yliopisto. http://urn.fi/URN:NBN:fi:hulib-201610122846.

Ropo A., Eriksson M., Sauer E., Lehtimäki H., Keso H., Pietiläinen T. \& Koivunen N. (2005). Jaetun johtajuuden särmät. Helsinki: Tallentum.

Sampson, E. (1998). Life as an Embodied Art: The Second Stage - beyond Constuctionism. Teoksessa Bayer B. M. \& Shotter J. (eds.) Reconstructing the Psychological Subject. Bodies, Practices and Technologies. London: Sage Publications, 21-32.

Silverman, D. (2008). A Very Short, Fairly Interesting and Reasonably Cheap Book about Qualitative Research. London: Sage.

Ståhle, P., Sotarauta, M. \& Pöyhönen, A. (2004). Innovatiivisten ympäristöjen ja organisaatioiden johtaminen. Teknologian arviointeja 19. Helsinki: Eduskunnan kanslian julkaisu 6/2004.

Suominen, J. (2013). Missä tiimiyrittäjyys? Yrittäjyyden eetoksen ja yrittäjyyskasvatuksen filosofisten lähtökohtien kriittistä arviointia. Väitöskirja. Acta Universitatis Tamperensis 1886.

Tienari, J.\& Meriläinen, S. (2016). Palvelukseen halutaan ajokoira: johtajan ulkonäkö ja esiintyminen. Helsinki: Siltala.

Vänskä, A. (2006). Vikuroivia vilkaisuja. Ruumis, sukupuoli, seksuaalisuus ja visuaalisen kulttuurin tutkimus. Väitöskirja. Helsingin yliopisto.

Wenger, E. (1998). Communities of Practice: Learning, Meaning and Identity. Cambridge, UK: Cambridge University Press.

Wilson, J. \& Thomson, A. (2006). The Making of Modern Management - British Management in Historical Perspective. New York: Oxford University Press. 


\section{KommentTi}

\section{Vapaus ja vastavuoroinen tunnustus työssä}

Työyhteisön kuuluu yhdessä sopia omista arvoistaan, tavoitteistaan ja pelisäännöistään. Samoin on sovittava, millä perustein tunnustus annetaan kunkin panoksesta yhteiseen hyvään.

HEIKKI PASANEN JA MERJA ALANKO-TURUNEN tarkastelevat artikkelissaan tunnustusta työn kontekstissa, jossa yksilöiden välinen suhde on institutionaalisten roolien, esimies-alaissuhteen välittämä. He puhuvat vertaisuuden tunnustamisesta. Ilmaisu juontunee tutkimuskohteena olevasta interventiomenetelmästä, vertaisryhmämentoroinnista.

On kuitenkin ongelmallista puhua filosofi Georg Wilhelm Friedrich Hegelin, saati "Hegelin kirjassaan esittämästä, tunnustuskäsitteestä”. Hegel kehitteli tunnustuksen käsitettä läpi uransa eri teoksissaan, ja niistä on vaikea esittää yhtä tulkintaa.

Filosofi Robert Williamsin perusteellinen teos aiheesta (1977) kritisoi muun muassa hegeliläisen poliittisen filosofin Alexandre Kojèven, yhteiskuntateoreetikko Jürgen Habermasin, filosofi ja sosiologi Axel Honneth Honnethin ja filosofi Ludwig Siepin tulkintoja Hegelin tunnustuksen käsitteestä ja herraorja-dialektiikasta

HEGELIN HENGEN FENOMENOLOGIA ja poliittinen teoria tutkii vapauden historiallisten, poliittisten ja institutionaalisten edellytysten kehitystä ennen muuta Euroopan historiassa. Jotkut tutkijat katsovat, että herran ja orjan dialektiikka analysoi feodaalista maaorjuusjärjestelmää (Cole 2004) ja varhaiskapitalistisia orjanomistusjärjestelmiä (Buck-Morss, 2009) siirtymävaiheena moderniin perustuslailliseen valtioon, jossa kaikkien kansalaisten oikeudet on tunnustettu.

Hegel seurasi tarkasti oman aikansa politiikkaa ja todisti muun muassa orjakapinaa, joka käynnistyi vuonna 1791 Ranskan rikkaimmassa siirtomaassa
Saint-Dominiguessa ja johti Haitin tasavallan syntyyn vuonna 1804 . Sen perustuslaki turvasi kaikille kansalaisille rotuun katsomatta kansalaisoikeudet.

Yhdysvallat pelkäsi Haitin esimerkin leviävän alueelleen, ja Napoleon päätti palauttaa orjuuden valtameren takaisiin siirtomaihin lähettäen kenraali Philippe Leclercin johtaman laivaston Haitiin. Keltakuume ja haitilaisten vastarinta löivät ranskalaiset, mutta tasavalta hajosi pitkään kestäneiden sotien tuloksena kahteen sotaherrojen hallitsemaan osaan. Orjakapina, jonka yksi tunnus oli "vapaus tai kuolema”, oli esikuvana Latinalaisen Amerikan kolonialismin vastaisille liikkeille.

TOINEN TULKINTAPA on irrottautua historiallisesta kontekstista ja nähdä tunnustus yksilön vapauden ja itsetietoisuuden yleisenä edellytyksenä. Yksilö voi tulla tietoiseksi vapaudestaan ja itsestään vain, jos niin ikään vapaa henkilö tai yhteisö tunnustaa tämän vapauden. Itsetietoisuus ja identiteetin muodostuminen ovat perustavasti riippuvaisia sosiaalisesta yhteisöstä. Tätä tulkintalinjaa edustaa niin kutsuttu nykyaikainen tunnustusteoria, jonka katsotaan syntyneen 1990-luvulla Charles Taylorin esseestä "Politics of recognition" (1992) ja Honnethin teoksesta The Struggle for Recognition. Honnethin teos The Moral Grammar of Social Conflicts (1996) nojautui Hegelin Oikeusfilosofiassa esittämään teoriaan eettisestä järjestyksestä (Sittlickeit, siveellisyys) ja etsi tunnustussuhteille psykologisia perusteita George Herbert Meadin sosiaalipsykologiasta ja Donald Winnicotin psykoanalyyttisesta teoriasta lapsen kehityksestä.

Honneth (1996) tarkastelee tunnustussuhteita perheessä, valtiossa ja kansalaisyhteiskunnassa. Hän kutsuu niitä 'rakkaudeksi', 'itsekunnioitukseksi' ja 'itsearvostukseksi'. Yksilö hakee tunnustusta ja rakentaa identiteettiään perheen, työyhteisön ja kansalaisjärjestöjen jäsenenä sekä oikeusvaltion kansalaisena. 